\title{
Problems in the treatment of malabsorption in CF
}

\author{
M. SINAASAPPEL, ${ }^{1}$ J. BOUQUET ${ }^{1}$ and H. J. NEIJENS ${ }^{2}$ \\ From the Department of Paediatrics, subdivision 'Gastroenterology and ${ }^{2}$ Respiratory Diseases, \\ Erasmus University and University Hospital Rotterdam/Sophia Children's Hospital, \\ Rotterdam, The Netherlands
}

\begin{abstract}
Sinaasappel, M., Bouquet, J. and Neijens, H. J. (Department of Paediatrics, Erasmus University and University Hospital Rotterdam/Sophia Children's Hospital, Rotterdam, The Netherlands). Problems in the treatment of malabsorption in CF. Acta Paed Scand Suppl 317.
\end{abstract}

Several factors play a role in the cause of malabsorption in CF. Besides the enzyme deficiency in the secretion of the exocrine pancreas, decreased bile-salt concentration in the gut may also be an important factor in the fat malabsorption. The contribution to the fat absorption by other lipases, such as lingual lipase and gastric lipase, remains to be proved. The therapeutic measures are only partly effective because of the breakdown of swalled enzymes by gastric acid. Some improvement is reached by using a new acid-resistant coating for the enzyme supplement. Newly developed and essential for its success is the application of small coated particles to prevent retention in the stomach, and the easy breakdown of the coating in an alkaline solution. The treatment of the bile salt deficiency has not been successful until now. A trial with additional Tween 80 , with the option of supplementing the detergent activity which was found to be successful in Crohn disease, was without marked success.

Malabsorption is one of the more serious problems in CF. The fat and protein digestion and absorption and, to a lesser extent, also the carbohydrate digestion are disturbed. The disorder of the intraluminal digestion is caused mainly by insufficiency of the exocrine pancreas, in particular by the decreased secretion of bicarbonate, lipase and trypsin. Moreover, the digestion is disturbed by a deficiency of bile salts in the proximal gut which results in a reduced emulsifying capacity and a decrease in enzyme induction.

The supposed high viscosity of the intestinal fluids may hamper the transport of digested products. This would explain many of the CF-related disorders, such as intestinal obstruction and ileus symptoms and the thick unstirred water layer on the brustiborder of the epithelium (1). Finally, a specific intracellular transport defect of bile salts has recently been suggested (2).

In the following survey, we consider the role of these factors in CF patients.

Enzymes

In the majority of CF patients, pancreatic enzyme deficiency is such that both fat and protein absorption is seriously diminished. The main enzymes involved are lipase, the lipase-colipase complex, lingual lipase, phospholipase, and the protein and carbohydrate splitting enzymes. This was repeatedly shown, among others, by Wong et al. (3) using the pancreozymin secretin stimulation test. Their results revealed that the enzyme activity of lipase reached only $3 \%$ of normal levels, whereas trypsin and chymotrypsin amounted to $30 \%$. However, the usual treatment consisting of the administration of supplemental pancreas extract is only partly effective. Fat absorption does improve, but without reaching a normal level. In this connection, DiMagno et al. (4) carried out a study of enzyme activity in the duodenum following the administration of pancreatic extracts. In the distal part of the duodenum, this resulted in $22 \%$ of the administered dose for trypsin activity and only $3 \%$ for the lipase activity. This was due to the fact that a great deal of the enzyme activity was lost in the stomach. 


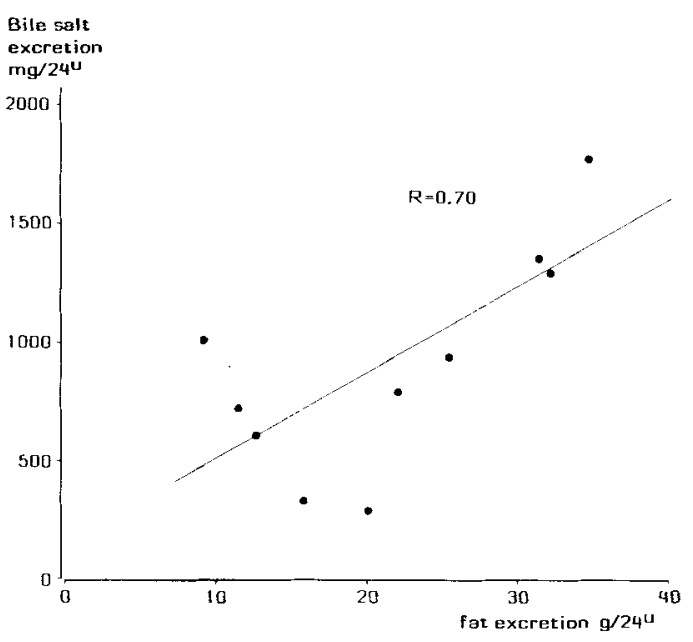

Fig. 1. Relation between fat and bile salt excretion in stool during pancreatine therapy.

Recently, Gaskin et al. (5) found that an important co-factor for the fat-splitting enzyme lipase was deficient in cystic fibrosis patients. It turned out that the degree of deficiency of this colipase correlated with the steatorrhoea-sometimes even better than lipase did. They concluded that colipase activity was an accurate measure of the physiological capacity for fat digestion, especially in those patients with marginal lipase output.

\section{Bicarbonate}

The amount of bicarbonate from the pancreas released into the duodenum is found to be decreased $(6,7)$, due to an inadequate neutralization of gastric acid and a relative low duodenal $\mathrm{pH}$. In CF patients with malabsorption, the bicarbonate discharge is below $10 \%$ of the normal value, but even patients without gastro-intestinal symptoms have an abnormal bicarbonate excretion. This will result in a decreased enzyme activity and a precipitation of glycocholic acid.

\section{Bile acids}

Apart from a deficiency in the enzyme activity and bicarbonate concentration in the duodenum the bile acid concentration in the duodenum is also decreased. The bile acid recirculation is disturbed, resulting in an increased faecal loss (8), probably due to a disorder of the absorption in the terminal ileum (2). This may lead to a reduction of the bile acid pool as well as a decreased excretion of bile acid in the duodenum. In addition, the low $\mathrm{pH}$ level in the duodenum due to the decreased bicarbonate excretion results in a precipitation of bile acid and finally some patients may have impaired liver function, which will result in a diminished bile acid synthesis. This low bile acid concentration in the duodenum will result in a hampered emulsification of fat. During a study of the effect of an improved preparation, we compared the effect of two different enzyme preparations on bile acid excretion. We found that the faecal fat excretion correlated positively with the faecal bile acid excretion when conventional preparations were given (Fig. 1).

Surprisingly, after the change in therapy, from the conventional enzyme preparation to the improved preparation, resulting in a better fat absorption, no effect could be shown on the bile salt excretion in the stool (Fig. 2). We concluded that bile salt malabsorption was not directly dependent on fat absorption and that loss of bile salts may contribute to the fat malabsorption, in contrast to the findings of Isenberg (9). 


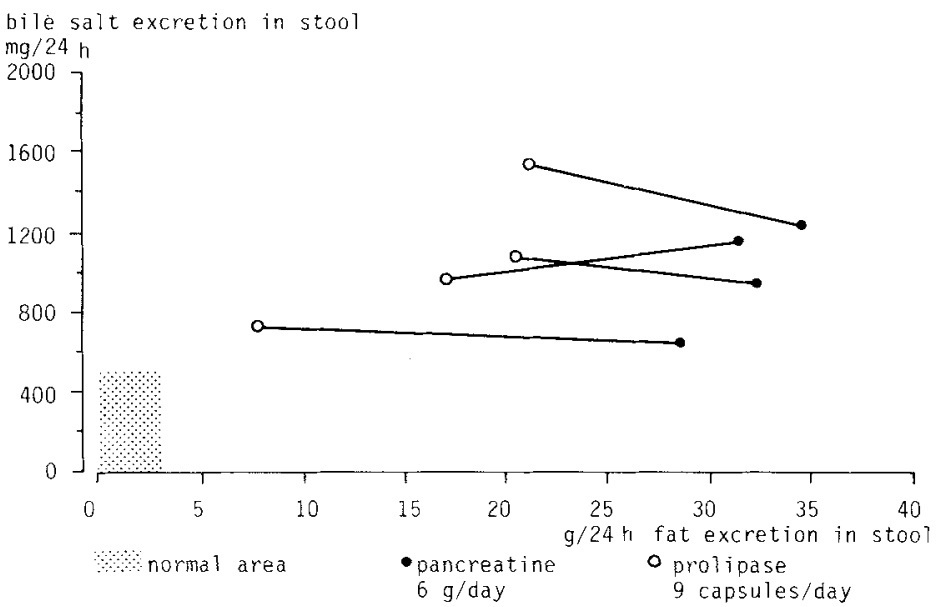

Fig. 2. Influence of $\mathrm{pH}$-sensitive microspheres on fecal bile salt and fat excretion in CF patients.

\section{Mucus}

Freye et al. (10) noticed that in CF patients a thick layer of mucus covered the surface of the brush border. Only recently, Wesley et al. (11) demonstrated a difference between normal and CF mucus in the gut. They found that $\mathrm{CF}$ mucins were enriched in glucose, galactose, $\mathrm{N}$-acetyl glucosamine and total carbohydrate per mg protein and per oligosaccharide chain. They speculated that hyperglycosylation with an associated increase in average chain length of carbohydrate side chain would increase the equivalent hydrodynamic volume of the mucin molecule and so result in enhanced viscosity and gelling. However, the dominant feature which controls the gelation of mucins appears to be their polymeric structure maintained by a disulfide-linked peptide (11). The possible effects of a thick unstirred mucus layer on intestinal absorption processes have hardly been explored until now.

\section{THERAPEUTIC CONSEQUENCES}

\section{Pancreatic enzyme supplementation}

Various methods have been attempted to protect enzymes against acids: coating of the enzymes as tablets, administration of sodium bicarbonate, blocking the production of gastric acid and coating of the enzymes in $\mathrm{pH}$ dependent microspheres. Sofar coated tablets have been shown to be useless as they do not disintegrate to deliver enzyme activity.

Recently, a new method has been developed for coating the enzymes in order to protect them against gastric acid. This coating is acid-resistant, but disintegrates in an alkaline environment. The size of the grain is such that a smooth passage through the pylorus is guaranteed. We-and several other workers $(12,13)$ have tested this new preparation to see to what extent the fat absorption was improved, in comparison with a conventional enzyme preparation. We found a significant decrease in the stool weight, expressed in grams per 24 hours. The fat absorption coefficient showed an increase, from $60 \%$ in patients with conventional enzyme therapy to $78 \%$ with low $(=6 \mathrm{caps} / \mathrm{day})$ and $77 \%$ with a high dose ( $=9 \mathrm{caps} /$ day) of acid-resistant coated microsphere enzyme preparations (Fig. 3). So these patients showed a much better fat absorption, although the total amount of supplemented enzymes expressed as enzyme activity remained almost the same. Furthermore, it turned out that there is an optimal effect in the majority of the patients, expressed 


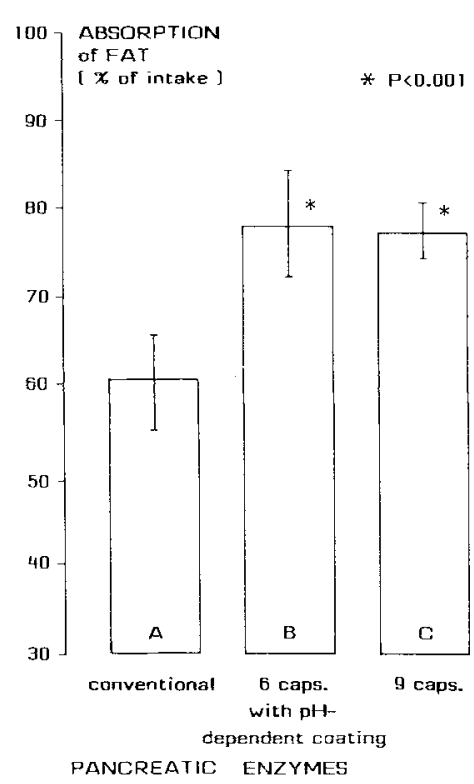

Fig. 3. Pancreatic enzymes.

as fat absorption rate, when a dose of six capsules of enzyme were given. Nine capsules a day did no better than six. For the protein digestion and absorption, we did not find any significant improvement in the treatment with acid-resistant coated enzymes. Our conclusion was that fat absorption in CF patients, not optimally correctable by the conventional pancreatic supplementation, was increased significantly by using this new acid-resistant coating. All the patients preferred the acid-resistant coated form because it was easier to administer, there were fewer intestinal symptoms and the fat allowance in the diet increased.

\section{Gastric acid influence on pancreatic enzymes}

Although various authors have claimed an improvement in the fat absorption as a result of cimetidine $(14,15)$; others have not been able to confirm these results $(16,17)$. In the case of treatment with pancreatic extracts, the extent of fat absorption is directly related to the production of gastric acid determined after maximal stimulation. However, although in our study (16) cimetidine in a low and a high dose reduced the maximal acid output significantly, the fat excretion did not alter at all (Table 1).

Peterson et al. (18) showed in adults that the gastric pH remained below 4 during cimetidine therapy ( $300 \mathrm{mg}$ with meals and at bedtime), only during the night, the $\mathrm{pH}$ raised over 4 . This observation leads one to expect that supplementary enzyme preparations during meals would be inactivated even if these patients received cimetidine. To

Table 1

\begin{tabular}{lll}
\hline & $\begin{array}{l}\text { MAO }(n=13) \\
(\mathrm{mmol} / \mathrm{h} \pm \mathrm{SD})\end{array}$ & $\begin{array}{l}\text { Fecat fat }(n=13) \\
(\mathrm{g} / 24 \mathrm{~h} \pm \mathrm{SD})\end{array}$ \\
\hline Pancreatine (3-5 g/day) & $8.39 \pm 2.81$ & $17.2 \pm 7.7$ \\
Pancreatine (3-5 g/day) + cimetidine (150-300 $\mathrm{mg} /$ day) & $6.10 \pm 2.46$ & $19.0 \pm 11.7$ \\
Pancreatine (3-5 g/day) + cimetidine (300-600 mg/day) & $4.20 \pm 2.08$ & $16.9 \pm 15.1$ \\
\hline
\end{tabular}


assess the effects of cimetidine in CF patients, one has to determine the long-term actual $\mathrm{pH}$ in the stomach, which has not been studied so far.

\section{Decreased mucus viscosity}

We studied the extent to which normal mucus viscosity might lead to an impaired absorption by oral administration of a mucolytic drug. $N$-acetylcystine is capable of breaking down the sulfide bonds and so decreasing the viscosity of the mucus. For this purpose, it is widely used as a diluting drug for sputum. In analogy to this we tried the effect of using it in the gut. We treated 12 patients with the conventional pancreatic enzyme therapy, and compared two week periods of 1 week with and without $N$ acetylcystine in a dose of $8 \mathrm{~g}$ per day. We did not observe any significant change in fat excretion when $\mathrm{N}$-acetylcystine was given as adjuvant therapy, although there was a slight decrease. Since a high dose of $N$-acetylcystine was given, this effect is probably of little importance.

\section{Bile salt deficiency}

King and Dubois $(19,20)$ both published results of the administration of a detergent (Tween 80 ) to patients with steatorrhoea related to bile salt deficiency and to control patients receiving cholestyramine, a bile salt sequestering agent. Both described a positive effect on the fat excretion in the stool. We studied the effect of Tween 80 administration ( 6 gram/day) to CF patients with steatorrhoea and increased bile salt loss in the stool. The results were disappointing, the fat excretion and the bile salt loss in the stool did not change at all, even with a high dose of Tween 80 (Table 2).

A definite conclusion cannot be drawn from these preliminary results, regarding the effect of bile salt; acid precipitation is a possibility, but not studied until now.

In summary, we have discussed four items. We stressed that enzymes and bicarbonate concentration are deficient, enzyme preparations are improving, while cimetidine as a therapy is debatable. The bile salt deficiency remains a problem, some CF patients lose much of their bile salts in the stool. It is possible that bile salt supplementation in a certain form will improve fat malabsorption. Finally, the intestinal mucus also seems to be abnormal, but treatment with a mucus solvent was not effective in our experience.

\section{REFERENCES}

1. Dische Z, di Sant Augere PA, Pallavicini C, Youles J. Composition of mucoprotein fractions from duodenal fluid of patients with cystic fibrosis of the pancreas and from emboles. Pediatrics 24; 74: 1959.

2. Fondacaro JD, Heubi JE, Kellogg FW. Intestinal bile acid malabsorption in cystic fibrosis: a primary mucosal cell defect. Pediatr Res 1982;16:494-98.

3. Wong LTK, Turtle S, Davidson AGF. Secretin pancreozymin stimulation test and confirmation of the diagnosis of cystic fibrosis. Gut 1982;23:744-50.

4. DiMagno EP, Malagelada JR, Go VLW, Moertel CG. Fate of orally ingested enzymes in pancreatic insufficiency. N Engl J Med 1977; 196: 1318-22.

5. Gaskin KJ, Durie PR, Lee L, Hill R, Forstner GG. Colipase and lipase secretion in childhoodonset pancreatic insufficiency. Gastroenterol 1984; 86: 1-7.

6. Gaskin KJ, Durie PR, Corey M, Wei P, Forstner GG. Evidence for a primary defect of pancreatic $\mathrm{HCO}_{3}$-secretion in cystic fibrosis. Pediatr Res 1982; 16:554-57.

7. Zoppi G, Shmerling DH, Gaburro D, Prader A. The electrolyte and protein contents and outputs in duodenal juice after pancreozymin and secretin stimulation in normal children and in patients with cystic fibrosis. Acta Paediatr Scand 1970; 59: 692-96.

8. Weber AM, Roy CC, Chartrand L et al. Relationship between bile acid malabsorption and pancreatic insufficiency in cystic fibrosis. Gut 1976; 17:295-99.

9. Isenberg JN, Hendrix PY, Cox KL. Effect of short-term cimetidine administration on fecal bile acid losses in cystic fibrosis. J Pediatr Gastroenterol Nutr 1983; 2: 447-51. 
10. Freye HB, Kurtz SM, Spock A, Capp MP. Light and electron microscopic examination of the small bowel of children with cystic fibrosis. J Pediatr 1964; 64:575-79.

11. Wesley A, Forstner J, Qureshi R, Mantle M, Forstner G. Human intestinal mucin in cystic fibrosis. Pediatr Res 1983; 17:65-69.

12. Khaw KT, Adeniyi-Jones S, Gordon D, Polombo J, Suskind RM. Efficacy of pancreatin preparations on fat and nitrogen absorptions in cystic fibrosis patients. Pediatr Res 1978; 12: no. 444 (abstract).

13. Mischler EH, Parrell S, Farrell PM, Odell GB. Comparison of effectiveness of pancreatic enzyme preparations in cystic fibrosis. Am J Dis Child 1982; 136: 1060-63.

14. Hubbard VS, Dunn GD, Lester LA. Effectiveness of cimetidine as an adjunct to supplemental pancreatic enzymes in patients with cystic fibrosis. Am J Clin Nutr 1980; 33: 2281-86.

15. Cox KL, Isenberg JN, Osher AB, Dooley RR. The effect of cimetidine on maldigestion in cystic fibrosis. J Pediatr 1979; 94: 488-92.

16. De Biéville F, Neijens HJ, Fernandes J, van Caillie M, Kerrebijn KF. Cimetidine as an adjunct to oral enzymes in the treatment of malabsorption due to cystic fibrosis. Acta Paediatr Scand 1981; 70: $33-37$.

17. Cortina LS, Pena LA, Salces CC, Castro HE. Cimetidine in cystic fibrosis. Effect on steatorrhoea and serum fatty acids. Acta Paediatr Belg 1980; 33:23-25.

18. Peterson WL, Barnett C, Feldman M, Richardson CT. Reduction of twenty-four-hour gastric acidity with combination drug therapy in patients with duodenal ulcer. Gastroenterol 1979; 77: $1015-20$.

19. King RFGJ, Howdle PD, Kelleher J, Losowsky MS. Synthetic detergents in bile-salt-deficient steatorrhoea. Clin Science 1979; 56:273-81.

20. Dubois JJ, Holt PR, Kuron GW, Hashim SA, Van Itallie TB. Effect of Tween 80 on cholestyramine-induced malabsorption. Proceedings of the Society for Experimental Biology and Medicine 1964. 